\title{
Healthcare System Functions in Iran and Successful Developing Countries Regarding Access to Universal Health Coverage: A Comparative Study
}

\author{
Nahid Hatam ${ }^{1}$, Yegane Partovi ${ }^{2}$, Seyed Reza Najibi ${ }^{3}$, Milad Ahmadi Marzaleh ${ }^{4,5,6,7,8}$ and Seyede Maryam Najibi ${ }^{9}{ }^{*}$ \\ ${ }^{1}$ Professor of Health Service Administration, School of Management and Medical Informatics, Shiraz University of Medical Sciences, Shiraz, Iran \\ 2PhD Candidate in Health Services Management, Iranian Center of Excellence in Health Management, School of Management and Medical Informatics, Tabriz \\ University of Medical Sciences, Tabriz, Iran \\ 33.MSc Economy, School of Economic, Management and Social, Shiraz University, Shiraz, Iran \\ ${ }^{4}$ Assistant Professor, Research Center for Emergency and Disaster Resilience, Red Crescent society of the Islamic Republic of Iran, Tehran, Iran. \\ ${ }_{5}^{5}$ Assistant Professor, Research Center for Health Management in Mass Gathering. Red Crescent society of the Islamic Republic of Iran, Tehran, Iran \\ ${ }^{6}$ Assistant Professor, Iran-Helal Institute, Red Crescent Society of the Islamic Republic of Iran, Tehran, Iran. \\ ${ }^{7} \mathrm{PhD}$ of Health in Disasters and Emergencies, Student Research Committee, Department of Health in Disasters and Emergencies, Health Human Resources \\ Research Center, School of Management and Medical Informatics, Shiraz University of Medical Sciences, Shiraz, Iran. \\ 8MPH of Health Policy, Health Policy Research Center, Institute of Health, Shiraz University of Medical Sciences, Fars, Iran. \\ ${ }^{9} \mathrm{PhD}$ Candidate of Health Services Management, Student Research Committee, School of Management and Medical Informatics, Shiraz University of Medical \\ Sciences, Shiraz, Iran
}

* Corresponding author: Seyede Maryam Najibi, Student Research Committee, School of Management and Medical Informatics, Shiraz University of Medical Sciences, Shiraz, Iran. Tell: 0989170503041; Email: m.najibi90@gmail.com

Received 2021 January 30; Revised 2021 May 18; Accepted 2021 June 05

\begin{abstract}
Background: Universal health coverage is considered a prerequisite for human health and security.

Objectives: The current study aimed to evaluate and compare the healthcare system functions in Iran with those in successful developing countries in terms of universal health coverage (UHC).

Methods: In this comparative study, three developing countries, namely Turkey, Thailand, and China were selected based on former studies, and the model presented by the World Health Organization in 2000 was used to compare and analyze the data. The required information from the selected countries was collected through searching the Pub Med and Scopus databases using the following keywords: "Health system review", "Health system transition", "International profiles of healthcare systems", "Financing", "Resource generation", "Service provision", "Universal health coverage", and "Health system reform".

Results: The evaluation of the healthcare system's function in four countries showed that the public sector's share of total health expenditures was much higher than the private sector in both Thailand and Turkey. The issues that need to be addressed include the integration of insurance funds and risk accumulation, as well as the existence of a strong buyer organization. The comparison of the payment system in the studied countries indicated that the per capita method was used in all domains of primary care, and the inpatient diagnostic group (diagnosis-related group), fee for service, and salaries and rewards were more focused in the context of hospitalization. The majority of hospitals in the studied countries were state-owned; however, the important point was the presence of different nonuniversity public hospitals in these countries, compared to Iran.

Conclusion: In general, one way to reach the UHC is to utilize the experiences of successful countries in establishing and maintaining this issue.
\end{abstract}

Keywords: Developing countries, Health system functions, Iran, Universal health coverage

\section{Background}

Today, many low and middle-income countries have insufficient access to high-quality healthcare services (1). In this regard, the sustainable development goals (SDG) plan was approved by the United Nations on September 25 th 2015 (2). This plan provides opportunities to renew international communities and the commitment of governments to improve healthcare services as an important component of development (3). The implementation of universal health coverage (UHC) until 2030 is one of the key objectives of SDG (4). The UHC is considered a prerequisite for human health and security, especially in low and middle-income countries (5). Moreover, in the SDG plan, it is defined as the entire world's population's access to highquality healthcare services without the concern for financial burden (6). The achievement of UHC has three general indicators. 1)The ideal is that all people in a country be covered by healthcare services. 2)Meanwhile, it should be noted that ideally all infrastructures for prevention, treatment, and rehabilitation should be effectively implemented, and the highest attainable standards of health must be realized. 3)Moreover, people should not be faced with extravagant costs and financial burdens in the application for medical services (7).

The global community aims to provide a solution to reduce financial poverty caused by healthcarerelated expenses and improve the general access to key healthcare services, even in wealthy countries by the focus on universal health coverage (8). In this regard, the UHC progress was first assessed by the World Bank and World Health Organization (WHO), claiming a successful expansion of UHC by addressing evidence on the progress of this plan in poor rural areas of high-income countries (9). However, there is 
low agreement on how they can make the necessary reforms to achieve UHC in low and middle-income countries (8). According to Rahman "all WHO member countries seek to provide UHC and have established policies to expand the health coverage. However, only 20 developing countries have had good progress in this area" (5). It should be noted that UHC modifications are mainly focused on low and middle-income countries with a few exceptions (10). In Iran, efforts have been made to improve UHC, based on the announcement of the general health policies, the Health System Reform plan, and the social-economic development plans of the country. Despite the efforts made in this field, Iran still has a long way to achieve UHC. It is possible to rely on the experiences of different countries that have been able to take effective measures in the implementation of UHC in a short term to expedite the process.

\section{Objectives}

Therefore, despite the research conducted on UHC, the current study comprehensively evaluated and compared the health system functions in Iran with those in successful developing countries in terms of UHC, with the focus on four health system functions. Include provision of health care services, resource generation, financing, and stewardship.

\section{Methods}

This applied cross-sectional study was conducted as a comparative project. It should be mentioned that both developed (e.g. Germany, Sweden, and Britain) and middle-income countries (e.g. Turkey, Malaysia, Thailand, China, South Korea, and Mexico) are among the countries that have realized UHC. Inclusion criteria to determine the countries' advancement toward UHC included major reforms in the healthcare system and the socio-economic level in terms of being in the category of developing countries. Therefore, three developing countries, namely Turkey, Thailand, and China were selected based on former studies, and the model presented by WHO in 2000 (11) was used to compare and analyze the data.

This model addresses four health system functions, including having custodianship; providing preventive and treatment services; producing resources, such as physical and human resources; and funding including collecting revenue, accumulating and distributing risk, purchasing services, providing health insurance, and planning payment mechanisms to service providers. The information required from the selected countries in 2017 were collected from PubMed and Scopus databases, using such keywords as "health system review", "health system transition", "international profiles of health care systems", "financing", "resource generation", "service provision", "universal health coverage", and "health system reform". Published articles and most up-to-date information uploaded on the WHO and World Bank websites of the countries under the study were used in this study.

\section{Results}

\subsection{Stewardship Function}

The Ministry of Health in Turkey plays the role of a coordinator and developer of laws and act as an organization that monitors all hospitals, healthcare centers, and institutions in the health and pharmaceutical industry through related headquarter units and offices, and making coordination between organizations, and regulation of laws in provinces (12). In Thailand, the Ministry of Health is in charge of healthcare services along with seven other governmental organizations. Furthermore, the public health ministry is responsible for the regulation of national health policies, as well as the management and leadership of government centers (13). In China, the central government is responsible for the regulation of national health policies and oversees health service providers. Moreover, the national family health and regulatory commission is the highest authority for health and treatment, although it was the responsibility of the Ministry of Health until 2013 (14). In Iran, the Ministry of Health and Medical Education and the Ministry of Cooperatives, Labor, and Social Welfare are the custodians of the healthcare system in the country (15).

\subsection{Financing Function}

According to the World Bank data published in 2016, China has had the lowest per capita income with the highest population in the world and highest life expectancy. Turkey, Thailand, and Iran have nearly the same population and life expectancy, while Turkey has the highest per capita income among them. Based on the evidence, Iran spends eight percent of its GDP in the healthcare sector. In addition, Iran's healthcare expenditure per capita $(\$ 1,564)$ and out-of-pocket (OOP) costs $(39 \%)$ are much higher, compared to the aforementioned countries (Table 1). According to the WHO Health Financing Guidelines in 2017, health financing policies and arrangements includes revenue collection and participation mechanisms, resource accumulation, and service purchases, which are assessed in the present study (17).

\section{2.1. Revenue Collection}

According to a WHO report, revenue collection includes the shares of government and private sectors, as well as OOP level (17). Health services in the selected countries are financed through a variety of sources, including tax, government resources, social health insurance, OOP payments, and other private sources. In this regard, the 


\begin{tabular}{lcccccc}
\hline Table 1. Socio-economic indexes of countries selected in 2016 (16) & & & \\
Countries & Population & Life expectancy & Per capita income & $\begin{array}{c}\text { Health Sector } \\
\text { share to GDP Ratio } \\
\text { (\%) }\end{array}$ & $\begin{array}{c}\text { Expenditure on } \\
\text { health per capita } \\
\text { (\$) }\end{array}$ & 00P costs (\%) \\
\hline Turkey & $79,512,000$ & 75.8 & 24,160 & 4 & 1,089 & 16 \\
China & $1,400,000,000$ & 76.1 & 15,500 & 5 & 761 & 36 \\
Thailand & $68,864,000$ & 74.9 & 16,100 & 4 & 635 & 12 \\
Iran & $80,277,000$ & 75.5 & 20,050 & 8 & 1,564 & 39 \\
\hline
\end{tabular}

contribution of the public and private sectors in providing healthcare expenditure is important. In the mentioned countries, the public sector has the highest share in Thailand, whereas the private sector has the highest share in Iran (Figure 1).

Evidence from 2000-2015 also showed that the health share of GDP in Iran was on the rise and the highest among the mentioned countries and that the government was increasing its share of the health budget. while 0OP after following the Health System
Reform has been declining, it still the highest rate OOP was observed in Iran, compared to the other three countries (Figures 2 and 3).

\subsubsection{Resource Accumulation}

According to a WHO report, resource accumulation refers to accumulated resources for health services provided by public and private organizations, such as the Ministry of Health, social insurance, private insurance, and NGOs (Table 2) (17).

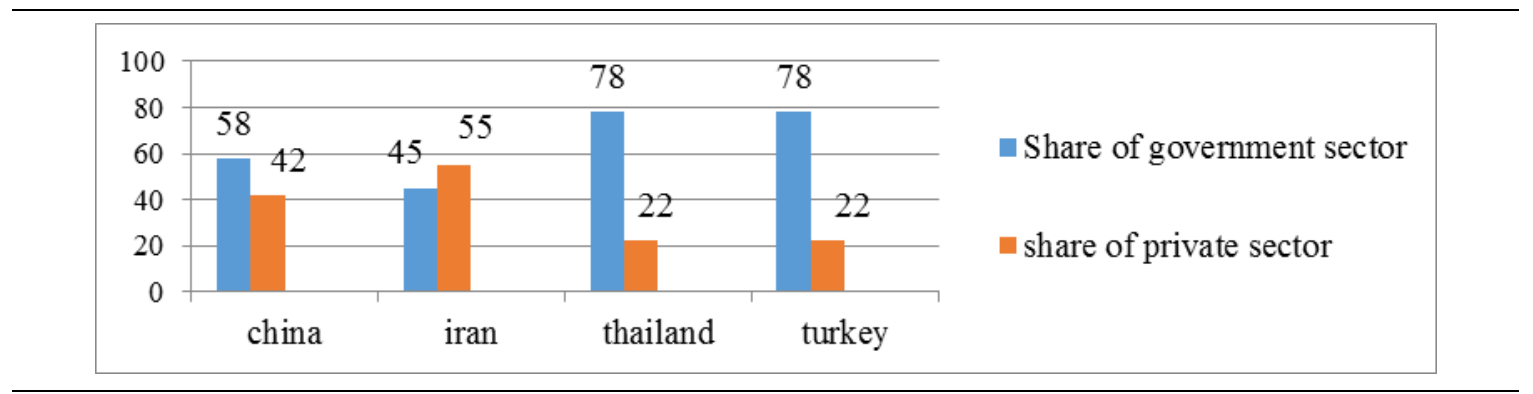

Figure 1. Share of government and private sectors of total health expenditures in $2016(16,12)$
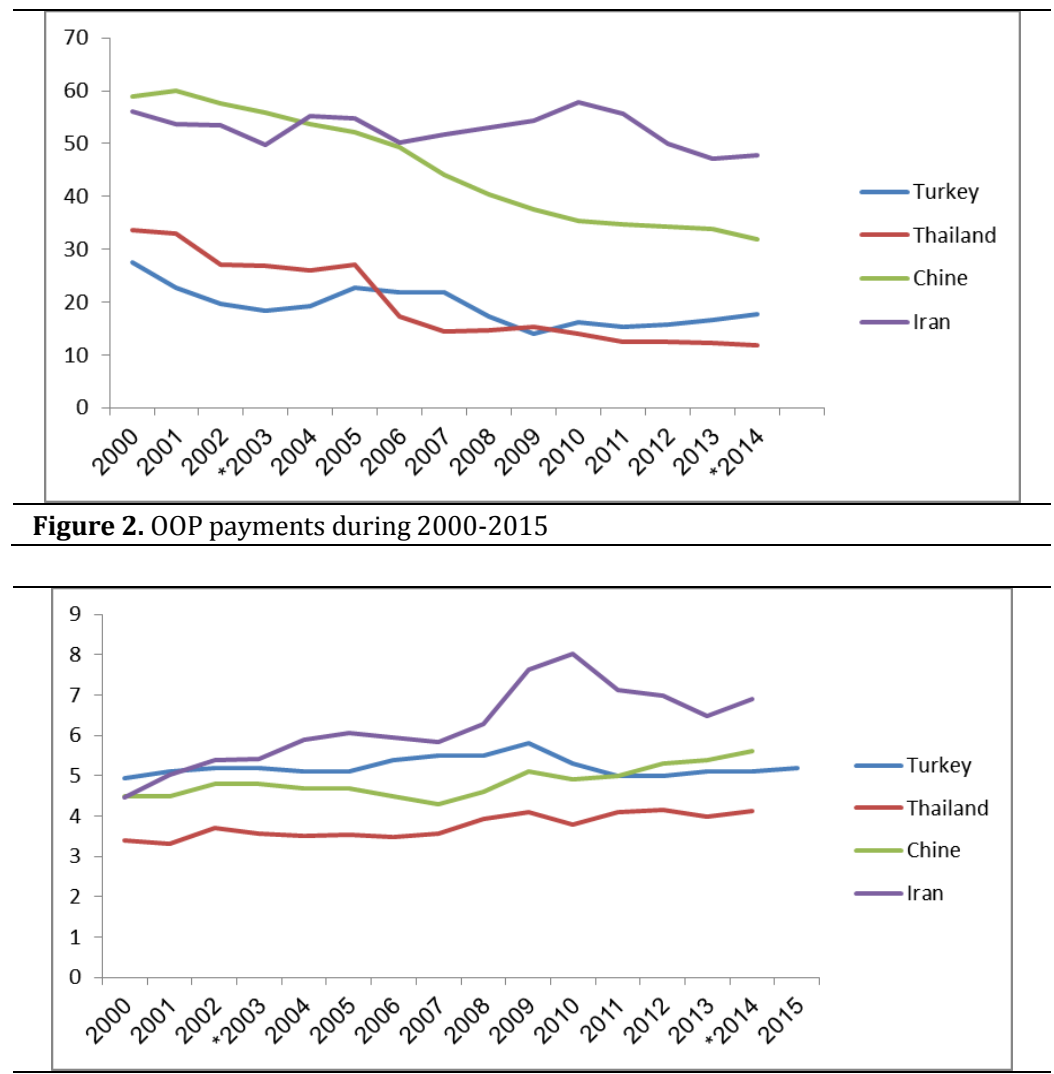

Figure 3. Health share of GDP during 2000-2015 
Hatam $N$ et al.

\begin{tabular}{|c|c|c|c|c|c|c|}
\hline \multirow[b]{2}{*}{ Country } & \multirow[b]{2}{*}{ Plan } & \multirow[b]{2}{*}{ Target population } & \multirow[b]{2}{*}{ Source of financing } & \multirow{2}{*}{$\begin{array}{c}\text { N Number } \\
\text { of people } \\
\text { covered }\end{array}$} & \multicolumn{2}{|c|}{ Payment to providers } \\
\hline & & & & & $\begin{array}{c}\text { Primary care/outpatient } \\
\text { payment }\end{array}$ & Hospital payment \\
\hline \multirow{3}{*}{ Thailand } & $\begin{array}{c}\text { Medical Benefits for } \\
\text { Government Staff } \\
(1963)\end{array}$ & $\begin{array}{l}\text { Government } \\
\text { employees, retirees, } \\
\text { their relatives }\end{array}$ & $\begin{array}{l}\text { Non-participatory } \\
\text { public tax }\end{array}$ & Six million & \multirow{3}{*}{$\begin{array}{c}\text { Outpatient Services: per } \\
\text { capita } \\
\text { Prevention services: per } \\
\text { capita + performance- } \\
\text { based payments }(20)\end{array}$} & \multirow{3}{*}{$\begin{array}{l}\text { Global payment system } \\
\text { based on diagnosis- } \\
\text { related groups (20) }\end{array}$} \\
\hline & $\begin{array}{c}\text { Social health } \\
\text { insurance (1990) }\end{array}$ & Private sector staff & $\begin{array}{l}\text { Tax on salaries, } \\
\text { tripartite participation }\end{array}$ & & & \\
\hline & $\begin{array}{l}\text { Universal coverage } \\
\qquad(2002)\end{array}$ & Other populations & $\begin{array}{l}\text { Non-participatory } \\
\text { public tax }\end{array}$ & $\begin{array}{c}47 \text { million } \\
(18-21)\end{array}$ & & \\
\hline \multirow{6}{*}{ Turkey } & Social insurance & $\begin{array}{l}\text { Private sector } \\
\text { employees, blue- } \\
\text { collar workers in the } \\
\text { public sector }\end{array}$ & Tax on salaries & 30 million & \multirow{6}{*}{$\begin{array}{l}\text { Family doctors: per capita } \\
\text { + specific coefficients for } \\
\text { specific demographic } \\
\text { groups (12) }\end{array}$} & \multirow{6}{*}{$\begin{array}{l}\text { Payment to hospital } \\
\text { doctors: monthly salary } \\
\text { and based on hospital } \\
\text { performance in the last } \\
\text { month(12) }\end{array}$} \\
\hline & $\begin{array}{l}\text { Government } \\
\text { employee's } \\
\text { retirement fund }\end{array}$ & Retired civil servants & $\begin{array}{l}\text { Participation of } \\
\text { employed urban } \\
\text { servants }\end{array}$ & & & \\
\hline & $\begin{array}{l}\text { Government official } \\
\text { employee insurance } \\
\text { program }\end{array}$ & Government officials & State budget & & & \\
\hline & $\begin{array}{l}\text { Self-employed } \\
\text { insurance }\end{array}$ & $\begin{array}{l}\text { Self-employed staff, } \\
\text { free trade and guilds } \\
\text { Demographic groups }\end{array}$ & Salary & & & \\
\hline & Green card & $\begin{array}{l}\text { below a certain level } \\
\text { of income } \\
\text { Integration of social }\end{array}$ & Government budget & & & \\
\hline & $\begin{array}{l}\text { Public health } \\
\text { insurance }\end{array}$ & $\begin{array}{l}\text { insurance, state } \\
\text { pension fund, } \\
\text { government staff } \\
\text { fund, green card and } \\
\text { self-employed }\end{array}$ & Government revenues & $\begin{array}{l}94 \% \text { of total } \\
\text { population } \\
(2008)(22- \\
24)\end{array}$ & & \\
\hline \multirow{3}{*}{ China } & $\begin{array}{l}\text { Urban insurance } \\
\text { based on employed } \\
\text { individuals }\end{array}$ & Urban staff & $\begin{array}{l}\text { Taxes, salaries, } \\
\text { government } \\
\text { participation }\end{array}$ & $\begin{array}{l}274 \text { million } \\
\text { people }\end{array}$ & \multirow{3}{*}{$\begin{array}{l}\text { General practitioners and } \\
\text { specialists: basic salaries + } \\
\text { performance-based } \\
\text { payment }(25)\end{array}$} & \multirow{3}{*}{$\begin{array}{c}\text { Hospital care: a } \\
\text { combination of OOP, } \\
\text { health insurance, and } \\
\text { government subsidies } \\
\text { The most common } \\
\text { method of payment for } \\
\text { hospitals (FFS) (25) }\end{array}$} \\
\hline & $\begin{array}{l}\text { Urban insurance } \\
\text { based on residential } \\
\text { status }\end{array}$ & $\begin{array}{l}\text { Non-urban } \\
\text { employed residents, } \\
\text { self-employed } \\
\text { people, healthy } \\
\text { students and adults }\end{array}$ & Government & $\begin{array}{l}299 \text { million } \\
\text { people }\end{array}$ & & \\
\hline & $\begin{array}{l}\text { Rural medical } \\
\text { cooperative plan }\end{array}$ & $\begin{array}{l}\text { Residents of rural } \\
\text { areas }\end{array}$ & Governmental & $\begin{array}{l}802 \text { million } \\
\text { people (26) }\end{array}$ & & \\
\hline \multirow{3}{*}{ Iran } & $\begin{array}{l}\text { Iran health insurance } \\
\text { organization }\end{array}$ & $\begin{array}{l}\text { Government staff, } \\
\text { self-employed } \\
\text { people, villagers, } \\
\text { other strata }\end{array}$ & Tax on salary & & \multirow{3}{*}{$\begin{array}{l}\text { The primary health care } \\
\text { network: monthly salaries } \\
\text { family doctor: per capita } \\
\text { (27) }\end{array}$} & \multirow{3}{*}{$\begin{array}{l}\text { Public hospitals for } \\
\text { physicians and clinical } \\
\text { medical personnel and } \\
\text { non-clinical staff: salary } \\
\text { + based on } \\
\text { performance, FFS, and } \\
\text { global pay (27) }\end{array}$} \\
\hline & Social security & $\begin{array}{l}\text { Salaried workers } \\
\text { (compulsory), } \\
\text { profession owners } \\
\text { and self-employed } \\
\text { people (optional) }\end{array}$ & $\begin{array}{l}\text { Employer and insured } \\
\text { participation }\end{array}$ & & & \\
\hline & Armed forces & $\begin{array}{l}\text { All soldiers and } \\
\text { relatives }\end{array}$ & $\begin{array}{l}\text { Per capita entitlement } \\
\text { to treatment, income } \\
\text { from funds and } \\
\text { property owned by the } \\
\text { organization, donations } \\
\text { and gifts (16) }\end{array}$ & & & \\
\hline
\end{tabular}

\subsubsection{Purchasing Services}

According to a WHO report, Purchasing Services refer to the allocation of funds to healthcare providers and include payment mechanisms, purchasing market structure, and organizational arrangements between the buyers and providers (17).

In Turkey, the functions of the buyer and provider were distinguished in 2006 following the transfer of social security organization centers to the Ministry of Health. Social security organizations and private insurances buy health services from the public and private sectors. The prices and regulations for the provision of service to the private and government institutions are determined by the Health Implementation Guide, and providers will only be reimbursed on the basis of these rules (13). In Thailand, the National Health Security Office, as an autonomous public organization, was established following the implementation of UHC plan. This organization purchases health services from stakeholders of the UHC. Following the establishment of this organization, Thailand's Ministry of Health separated the duty of health service purchasing from health service provision (14). In China, government agencies, as buyers and third-party payers, have limited bargaining power for low rates and are faced with restrictions in monitoring the quality of offered services and the behavior of the providers (25). In Iran, the private sector in cities plays a major role in providing outpatient and inpatient diagnostic and treatment services and supplying drugs for the suppliers. However, the existing contracts are too simple in dealing with such a sensitive issue. In addition, there is almost no capacity to deal with the 
complexities of making a contract with service buyers and conclude specific contracts based on the quality and performance of the providers (16).

In this area, the mechanism of payment to service providers is presented in Table 3.

\subsection{Service Provision Function}

4.4. Resource Production Function

\subsubsection{Physical Resources}

Following the implementation of the health transition plan of hospitals affiliated with the Social Security Organization, these hospitals joined the Ministry of Health hospitals in Turkey, and the total number of hospitals managed by the Ministry of Health reached 840 in 2011. In 2010, the social security organization signed contracts with 421 private hospitals to promote the private sector (13). The number of hospitals in China increased from 1,949. The number of hospitals in $2012(17,023)$ was 2.5 times that of 1978 , and $42 \%$ of them were private hospitals (25). In Iran, more than $70 \%$ of medical institutions are affiliated with medical universities, which operate directly under the supervision of the Ministry of Health (30). In terms of the number of hospital beds, the results showed that Iran had a shortage of beds compared to the other mentioned countries (Figure 4).

\begin{tabular}{|c|c|c|c|c|c|}
\hline \multirow{6}{*}{$\begin{array}{l}\text { Service } \\
\text { provision }\end{array}$} & \multirow[b]{2}{*}{ Country } & \multicolumn{2}{|l|}{$\begin{array}{ll}\text { Sector } \\
\end{array}$} & \multirow[b]{2}{*}{ Primary health care } & \multirow[b]{2}{*}{ Second and third-level care } \\
\hline & & $\begin{array}{c}\text { Governmental and quasi- } \\
\text { governmental }\end{array}$ & Private & & \\
\hline & Turkey & $\begin{array}{l}\text { Ministry of health, } \\
\text { university hospitals, } \\
\text { ministry of defense } \\
\text { hospitals }\end{array}$ & $\begin{array}{c}\text { Private } \\
\text { hospital, } \\
\text { charity } \\
\text { hospitals, } \\
\text { outpatient } \\
\text { clinics, } \\
\text { independent } \\
\text { general } \\
\text { practitioners }\end{array}$ & $\begin{array}{l}\text { Provision of free services in the } \\
\text { form of a family doctor } \\
\text {-Provision of chronic disease } \\
\text { prevention services, pregnancy } \\
\text { care, neonates, midwifery } \\
\text { services, vaccination, family } \\
\text { planning } \\
\text {-Provision of services in health } \\
\text { centers (by family doctors and } \\
\text { family health workers) } \\
\text {-Practitioners and private clinics } \\
\text { (contract conclusion based on } \\
\text { performance and per capita) }\end{array}$ & $\begin{array}{l}\text { Level two in general } \\
\text { hospitals } \\
\text { Level three in university } \\
\text { hospitals (24-28) }\end{array}$ \\
\hline & Thailand & $\begin{array}{l}\text {-Ministry of Health, } \\
\text { university hospitals, } \\
\text { Ministry of Defense } \\
\text { hospitals, Red Cross }\end{array}$ & $\begin{array}{l}\text { Private } \\
\text { hospitals, } \\
\text { outpatient } \\
\text { clinics }\end{array}$ & $\begin{array}{l}\text {-Provided by a dedicated unit for } \\
\text { primary care or CUP covered by } \\
\text { the universal coverage plan } \\
\text {-Each primary care providing } \\
\text { unit comprises of several health } \\
\text { centers and a hospital. }\end{array}$ & $\begin{array}{c}\text { Provided by provincial and } \\
\text { regional hospitals with level } \\
1 \text { referrals }(14,29)\end{array}$ \\
\hline & China & $\begin{array}{l}\text { Urban community } \\
\text { hospitals, Ministry of } \\
\text { Health, university } \\
\text { hospitals }\end{array}$ & $\begin{array}{l}\text { Private } \\
\text { hospitals, } \\
\text { outpatient } \\
\text { clinics }\end{array}$ & $\begin{array}{l}\text {-Provided through rural } \\
\text { physicians and health workers in } \\
\text { rural clinics and urban } \\
\text { community hospitals }\end{array}$ & $\begin{array}{l}\text { Specialist services provided } \\
\text { by specialists without } \\
\text { referral from a general } \\
\text { practitioner }(16,26)\end{array}$ \\
\hline & Iran & $\begin{array}{l}\text { - Ministry of Health, } \\
\text { university hospital, oil } \\
\text { company, Ministry of } \\
\text { Defense, social security, } \\
\text { relief committee }\end{array}$ & $\begin{array}{l}\text { Private } \\
\text { hospitals, } \\
\text { outpatient } \\
\text { clinics }\end{array}$ & $\begin{array}{l}\text { - Provided by health centers } \\
\text { (Behvarz) in villages and rural } \\
\text { health centers and health centers } \\
\text { in cities and comprehensive } \\
\text { health services centers }\end{array}$ & $\begin{array}{l}\text { Level two services provided } \\
\text { by city hospitals and level } \\
\text { three specialized and } \\
\text { academic hospitals (30) }\end{array}$ \\
\hline
\end{tabular}

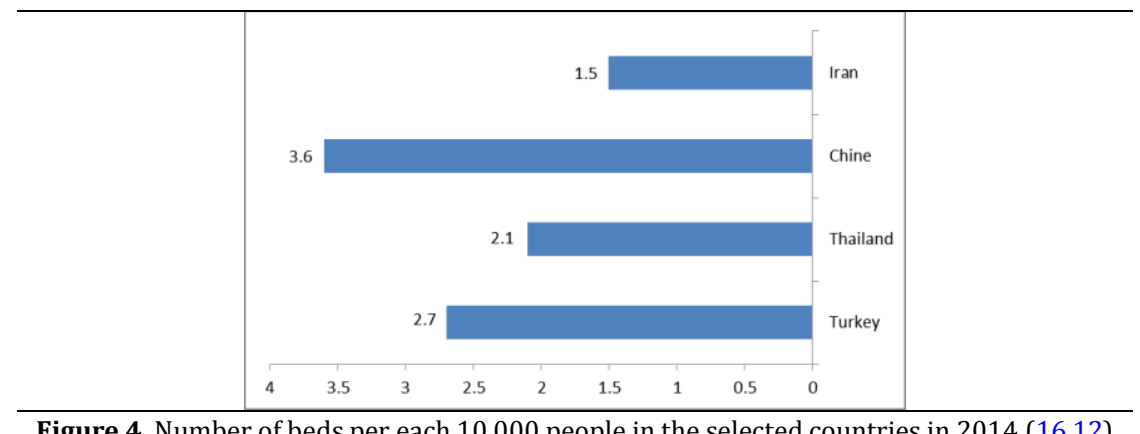

Figure 4. Number of beds per each 10,000 people in the selected countries in $2014(16,12)$

\subsubsection{Human Resources}

Despite the increase in the number of healthcare workers in Turkey, there are still shortages at many levels and inadequate geographical distribution of staff in this country. Among the WHO countries in Europe, Turkey is ranked first and second in terms of low proportion of nurses and physicians in the population (31). In China, there are also challenges in the distribution of human resources between urban and rural areas. Lack of staff in primary health care system and relatively low education level of the healthcare professions are among major challenges in 
the field of human resources (25).

Iran faces human resource shortage, compared to other three studied countries. In the past few years, there has been an increase in the ratio of general practitioners to specialized physicians, whereas the number of nurses and midwives has decreased compared to other Asian and European countries (16) (Table 4).

\begin{tabular}{l|ccccc}
\hline Table 4. Indexes of human resources in the selected countries & & & \\
& Index & Turkey (2015) & Thailand (2015) & China (2015) & Iran (2014) \\
\cline { 2 - 6 } & Ratio of nurses per 1000 people & 2.6 & 2.2 & 2.3 & 1.5 \\
\cline { 2 - 6 } Human resources & Ratio of physicians per 1000 people & 1.7 & 0.047 & 1.8 & 1.4 \\
& Ratio of midwives per 1000 people & 2.6 & 2.2 & 2.3 & 1.5 \\
& Ratio of pharmacists per 1000 people & 0.035 & 0.18 & 0.3 & 0.22 \\
\hline
\end{tabular}

\section{Discussion}

\subsection{Stewardship}

Evaluation of the health system's function in these countries showed that in the area of stewardship, healthcare organizations are fundamentally under the supervision of the Ministry of Health in many countries. Meanwhile, the lack of focus on health management in Thailand and Turkey regardless of the presence of independent organizations and provincial health offices is significant. The health transformation program in Turkey was implemented to redefine the role of the Ministry of Health by strengthening its stewardship and policymaking role. This led to the optimal use of health financing sources and the delegation of executive responsibility to new organizations $(14,32)$. In Iran, the functional failure of the health system to achieve its goals is due to structural disruption and the weakness of the stewardship function of the Ministry of Health. This was repeatedly addressed by various policymakers for more than a decade, and sporadic interventions were carried out in this regard (33). In this context, Jabari et al. proposed such mechanisms as transferring healthcare delivery to medical universities, transferring some welfare services to municipalities or the Ministry of Welfare, and utilizing the capacity of the private sector in providing healthcare services in order to decentralize the healthcare system (34).

\subsection{Financing}

In terms of financing function in the field of revenue collection, the results showed that the public sector's share of total healthcare services spent in both Thailand and Turkey was much higher than the private sector. However, this ratio is slightly higher in China and roughly equal in Iran. Therefore, one of the important challenges in Iran is the disproportionate share of public and private sectors in health expenditure. Iran is ranked $112^{\text {th }}$ in terms of OOP costs, and this index with $(47.8 \%)$ is the main source of financing in Iran (12). In general, OOP costs for health services are one of the major challenges of households, especially in low and middle-income countries, such as Iran. In this respect, Reshadat et al. (2017) reported the OOP rate to be $52.1 \%$, suggesting a significant decrease in OOP costs and an increase in the role of the government in financial support after the implementation of the development plan (35). Moreover, Piroozi et al. confirmed these results in Kurdistan province (36). In this respect, Doshmangir et al. marked a significant decrease in OOP costs in Turkey, owing to the use of prepayment, an increase in the government role, and the application of government revenue resources (37). Therefore, further steps are suggested to be taken to achieve the objectives of the UHC in Iran. In addition, Pazouki et al. proposed some measures for the improvement of the function of financing in Iran's health system, including the use of tax system in financial policies, defining tariffs for healthcare services based on final costs, and strengthening the necessary infrastructures for the activity of the private sector (38). Therefore, revenue collection should be directed toward public resources and the creation of new sources, such as taxes on harmful commodities (cigarette, soft drinks, and junk food), the stability and sustainability of revenues in the health sector, and the proper and regular allocation of budget.

The results of the present study indicated that in the area of resource accumulation on the subject of insurance reform in the studied countries, the issue of integration of insurance funds, risk accumulation, and the existence of a strong buyer organization should be considered. In Iran, the presence of multiple insurance companies with different franchise fees and prepayment levels, unfair premiums received by individuals, inequality and disagreement regarding the insurance commitments in paying health expenditures, and the uncertain status of people in income deciles to support the government, given their financial strength, are among the challenges in the area of revenue collection and accumulation. Other challenges include overlap in statistics, the inefficiency of the insurer as a buyer, lack of necessary information structures and failed implementation of electronic health records, presence of a large informal economic sector in the country, and posing obstacles to social security coverage $(27,30)$. In this context, Maher et al. (2017) declared that the accumulation of insurance makes accountability for the actual needs of the insured, controls and reduces the costs, and improves evaluation, monitoring, and policy-making in the insurance field (39). 
Therefore, the role of insurance companies must be strengthened as the powerful buyers in the health system of Iran. Moreover, Bazyar et al. (2016) evaluated the measures to reduce multiplication and fragmentation in the health insurance system of Iran and proposed the integration of policies and small funds with low financial resources as the first step in moving toward the integration of all funds. This way the majority of processes become unified, structural integration won't be difficult, and there will be fewer operational challenges in the way of full integration (40). The World Health Organization's recommenddations for pooling include:1) Increase the redistribution capacity between insurance funds. 2) transparency of financial flows of insurance funds. 3) Insurance funds complement each other in terms of population coverage and services. (17).

In the area of service purchasing, a comparison of the payment systems in the studied countries showed that the per capita method has been used in all primary care centers, and the inpatient diagnostic related group (DRG), fee-for-service (FFS), and salaries and rewards are more focused in the context of hospitalization. In Iran, FFS is the dominant payment method at the second and third level service. Studies showed that, other than motivating the providers to induce demand, FFS had little to do with the quality of service provided by the provider and the consequences $(27,30)$. Meanwhile, the DRG system motivates hospitals to reduce costs and does not affect the motivation of patients and physicians (41). In this regard, Babashahy et al. (2017) proposed a hybrid payment model to providers at various levels. Based on this model, the best payment methods at first, second, and third levels are FFS and a combination of DRG and performance-based payment, respectively, and FFS for outpatient services (42). Therefore, it is recommended to move towards a kind of purchasing that addresses the health needs of the community, considers the performance and motivation of the service providers, and promotes the desirable behavior health service providers.

\subsection{Service provision}

Given the low share of health in GDP compared to Iran, all the three countries had an average child mortality rate of below one year and under five years per thousand live births. Moreover, their maternal mortality per hundred thousand is far fewer from Iran. The study conducted by Ayubi et al. (2016) evaluated the mortality trends of infants aged below five years old from 1970 to 2015. The results indicated that Iran has been successful in these indicators by using prevention programs; however, more serious efforts and interventions are required, compared to other countries (43). Meanwhile, the lack of equitable access to health services across geographical areas is one of the challenges in Iran. In the rural areas, the first-level services are provided appropriately and actively, while these services are provided in a poor condition in Suburbs . In rural and deprived areas, second and third-level health services are provided less frequently, compared to large and developed cities due to the lack of necessary infrastructure, equipment, and manpower in rural and deprived areas $(27,30)$.

\subsection{Resource production}

According to the results, the majority of hospitals in the studied countries are state-owned; however, the important point is the presence of different nonuniversity public hospitals in these countries, compared to Iran. In addition, the comparison of physician density per thousand population showed that almost all the selected countries are at the same level and Iran is not experiencing a shortage of physicians compared to other countries. In addition, the comparison of the ratio of beds to population indicates a shortage of hospital beds in Iran. In the same line, Darzi Ramandi et al. (2016) evaluated health resource indicators in different provinces of Iran. The results of their study indicated the unfair distribution of health resources, including physicians and hospital beds. In the mentioned study, it was suggested that the policymakers in the realm of health should focus on scientific principles and specific standards in the distribution and allocation of health resources (44). Therefore, attention must be paid to increasing the hospital beds, as well as their fair distribution throughout the country.

\section{Conclusion}

In general, one way to reach the UHC is to utilize the experiences of successful countries in establishing and maintaining this plan. In the present study, results showed that the success factors of the studied countries included the following: increase the share of public sector in total health resources, reduced OOP payments, , decreased multiplication o insurance companies, strategic purchasing, payment methods with a specified limit to reduce costs, and having a consistent program. . In Iran, policy-makers and service providers in the health system can lay a proper foundation for achieving UHC by the adoption of the mentioned strategies and processes.

\section{Footnotes}

Authors' Contribution: Nahid Hatam and Seyede Maryam Najibi were responsible for the study conception and design and supervised the whole the study. Nahid Hatam, Yegane Partovi, Seyed Reza Najibi, Milad Ahmadi Marzaleh, and Seyede Maryam Najibi prepared the first draft of the manuscript. Nahid Hatam, Yegane Partovi, Seyed Reza Najibi, 
Milad Ahmadi Marzaleh, and Seyede Maryam Najibi conducted the data analysis and supervised the study. All authors have read and approved the final manuscript.

Conflicts of Interest: The authors have no conflict of interest regarding the publication of the study.

Informed Consent: None

Funding/Support: None.

Financial Disclosure: None.

\section{References}

1. Asante $\mathrm{AD}$, Irava $\mathrm{W}$, Limwattananon $\mathrm{S}$, Hayen $\mathrm{A}$, Martins J, Guinness L, et al. Financing for universal health coverage in small island states: evidence from the Fiji Islands. BMJ Global Health. 2017;2(2):e000200. doi: 10.1136/bmjgh-2016000200. [PubMed: 28589017].

2. Kieny MP, Bekedam H, Dovlo D, Fitzgerald J, Habicht J, Harrison G, et al. Strengthening health systems for universal health coverage and sustainable development. Bull World Health Organ. 2017;95(7):537-9. doi: 10.2471/BLT.16.187476. [PubMed: 28670019].

3. Osborn D, Cutter A, Ullah F. Universal Sustainable Development Goals: understanding the transformational challenge for developed countries. Stakeholder: Report of a study by Stakeholder Forum; 2015.

4. Islam MR, Rahman MS, Islam Z, Sultana P, Rahman MM. Inequalities in financial risk protection in Bangladesh: an assessment of universal health coverage. Int J Equity Health. 2017;16(1):59. doi: 10.1186/s12939-017-0556-4. [PubMed: 28376808].

5. Rahman MM, Karan A, Rahman MS, Parsons A, Abe SK, Bilano V, et al. Progress toward universal health coverage: a comparative analysis in 5 South Asian countries. JAMA Intern Med. 2017;177(9):1297-305. doi: 10.1001/jamainternmed.2017.3133. [PubMed: 28759681].

6. Kutzin J. Health financing for universal coverage and health system performance: concepts and implications for policy. Bull World Health Organ. 2013;91(8):602-11. doi: 10.2471/BLT. 12.113985. [PubMed: 23940408].

7. Beattie A, Yates R, Noble DJ. Accelerating progress towards universal health coverage in Asia and Pacific: improving the future for women and children. BMJ Global Health. 2016; 1(Suppl 2):i12-8. doi: 10.1136/bmjgh-2016-000190. [PubMed: 28588989].

8. Lagomarsino G, Garabrant A, Adyas A, Muga R, Otoo N. Moving towards universal health coverage: health insurance reforms in nine developing countries in Africa and Asia. Lancet. 2012;380(9845):933-43. doi: 10.1016/S0140-6736(12)611477. [PubMed: 22959390].

9. World Health Organization. Tracking universal health coverage: first global monitoring report: Geneva: World Health Organization; 2015.

10. McIntyre D, Ranson MK, Aulakh BK, Honda A. Promoting universal financial protection: evidence from seven low-and middle-income countries on factors facilitating or hindering progress. Health Res Policy Syst. 2013;11(1):36. doi: 10.1186/1478-4505-11-36. [PubMed: 24228762].

11. World Health Organization. The world health report 2000: health systems: improving performance. Geneva: World Health Organization; 2000.

12. Tatar M, Mollahaliloğlu S, Şahin B, Aydın S, Maresso A, Hernández-Quevedo C. Turkey: Health system review. Geneva: World Health Organization; 2011.

13. World Health Organization. The Kingdom of Thailand health system review. Manila: WHO Regional Office for the Western Pacific. Geneva: World Health Organization; 2015.

14. Meng $\mathrm{Q}, \mathrm{Xu} \mathrm{L}$. Monitoring and evaluating progress towards universal health coverage in China. PLoS Med. 2014; 11(9):e1001694. doi: 10.1371/journal.pmed.1001694. [PubMed: 25243903].
15. Manenti A. Health situation in Iran. Med J Islam Republic Iran. 2011;25(1):1-7.

16. World Health Organization. Western pacific country health information profiles. Geneva: World Health Organization; 2010.

17. Kutzin J, Witter S, Jowett M, Bayarsaikhan D. Developing a national health financing strategy: a reference guide. Geneva: World Health Organization; 2017.

18. Paek SC, Meemon N, Wan TT. Thailand's universal coverage scheme and its impact on health-seeking behavior. Springerplus. 2016;5(1):1952. doi: 10.1186/s40064-0163665-4. [PubMed: 27933235].

19. Somkotra T, Lagrada LP. Payments for health care and its effect on catastrophe and impoverishment: experience from the transition to Universal Coverage in Thailand. Soc Sci Med. 2008;67(12):2027-35. doi: 10.1016/j.socscimed.2008.09.047. [PubMed: 18952336].

20. Manus JM. Thailand's Universal Coverage Scheme: achievements and challenges: an independent assessment of the first 10 years (2001-2010). Synthesis report. Thailand: Health Insurance System Research Office; 2012.

21. Doshmangir L, Rashidian A, Bazyar M. Universal health coverage in Thailand: achievement and experiences learned. Hakim Res J. 2015;18(3):217-32.

22. Menon R, Mollahaliloglu S, Postolovska I. Toward universal coverage: Turkey's green card program for the poor. Washington DC: World Bank; 2013.

23. Yardim MS, Cilingiroglu N, Yardim N. Catastrophic health expenditure and impoverishment in Turkey. Health Policy. 2010;94(1):26-33. doi: 10.1016/j.healthpol.2009.08.006. [PubMed: 19735960].

24. Maeda A, Araujo E, Cashin C, Harris J, Ikegami N, Reich MR. Universal health coverage for inclusive and sustainable development: a synthesis of 11 country case studies. Washington DC: World Bank Publications; 2014.

25. Mossailos E, Djordjevic A, Osborn R, Sarnak D. International profiles of health care systems: Australia, Canada, China, Denmark, England, France, Germany, India, Israel, Italy, Japan, the Netherlands, New Zealand, Norway, Singapore, Sweden, Switzerland, Taiwan, and the United States. New York: The Commonwealth Fund; 2017.

26. Chen M, Zhao Y, Si L. Who pays for health care in China? The case of Heilongjiang province. PloS One. 2014;9(10):e108867. doi: 10.1371/journal.pone.0108867. [PubMed: 25271768].

27. Janati A, Maleki MR, Gholizadeh M, Narimani M, Vakili S. Assessing the strengths \& weaknesses of family physician program. Knowl Health. 2010;4(4):38-43.

28. Akhavan Behbahani A, Alidoost S, Masoudi Asl I, Rahbari Bonab M. Investigating the performance of Iran's health insurance organization and providing solutions for improvement: a mixed method study. J Iran Health Insur. 2018;1(3):88-96.

29. Hanvoravongchai P. Health financing reform in Thailand: toward universal coverage under fiscal constraints. Washington DC: World Bank; 2013.

30. Ferdosi M, Vatankhah S, Khalesi N, Ebadi Fard Azar F, Ayoobian A. Designing a referral system management model for direct treatment in social security organization. $J$ Mil Med. 2012;14(2):129-35.

31. Atun R, Aydın S, Chakraborty S, Sümer S, Aran M, Gürol I, et al. Universal health coverage in Turkey: enhancement of equity. Lancet. 2013;382(9886):65-99. doi: 10.1016/S01406736(13)61051-X. [PubMed: 23810020].

32. Yasar GY. Health transformation programme in Turkey: an assessment. Int J Health Plan Manag. 2011;26(2):110-33. doi: 10.1002/hpm.1065. [PubMed: 21674612].

33. Damari B, Vosoogh-Moghaddam A, Delavari A. How does the ministry of health and medical education of iran protect the public benefits? Analysis of stewardship function and the way forward. Hakim Res J. 2015;18(2):94-104.

34. Jabbari H, Tabibi J, Delgoshaii B, Mahmoudi M, Bakhshian F. Comparative study of decentralization mechanisms in health care delivery in different countries and suggesting a model for Iran. Health Manag J. 2007;10(27):33-40. 
35. Reshadat S, Najafi F, Karami-Matin B, Soofi M, Barfar E, RajabiGilan N, et al. Measuring financial protection in hospitalized patients after the health sector evolution plan in Iran. Health Scope. 2017;6(4):e63163. doi: 10.5812/jhealthscope.63163.

36. Piroozi B, Rashidian A, Moradi G, Takian A, Ghasri H, Ghadimi T. Out-of-pocket and informal payment before and after the health transformation plan in Iran: evidence from hospitals located in Kurdistan, Iran. Int J Health Policy And Manag. 2017;6(10):573-86. doi: 10.15171/ijhpm.2017.16. [PubMed: 28949473].

37. Doshmangir L. Assessment of Turkey's achievements in universal health coverage. Hakim Res J. 2015;18(3):233-45.

38. Pazouki M, Rezaii A, Pazouki M. Effectiveness of methods of financing the health sector in the economy of Iran. The Fifth Conference of the financing system in Iran, Tehran, Iran; 2012.

39. Maher A, Bahadori M, Ravangard R. The integration of health insurance funds as a reform approach in Iran. Shiraz E Med J. 2017;18(2):e45600. doi: 10.17795/semj45600.
40. Bazyar M, Rashidian A, Kane S, Mahdavi MRV, Sari AA, Doshmangir L. Policy options to reduce fragmentation in the pooling of health insurance funds in Iran. Int $J$ Health Policy Manag. 2016;5(4):253-8. doi: 10.15171/ijhpm.2016.12. [PubMed: 27239868].

41. Hajimahmoudi H, Zahedi F. Justice in the healthcare system: payment and reimbursement policies in Iran. Iran J Med Ethics Hist Med. 2013;6(3):1-16.

42. Babashahy S, Baghbanian A, Manavi S, Sari AA, Manesh AO, Ronasiyan R. Towards reforming health provider payment methods: evidence from Iran. Health Scope. 2017;6(1):e33575. doi: 10.5812/jhealthscope.33575.

43. Ayubi E, Mansori K, Ahmadi Pishkoohi M, Khazaei S. Children mortality in Iran: Moving ahead with the sustainable development goals. Int J Pediatr. 2016;4(6):1829-31.

44. Ramandi SD, Niakan L, Aboutorabi M, Noghabi JJ, Khammarnia M, Sadeghi A. Trend of inequality in the distribution of health care resources in Iran. Galen Med J. 2016;5(3):122-30. 